\title{
Karl Barth's understanding of mission: The Church in relationship ${ }^{1}$
}

\author{
W Bentley ${ }^{2}$ \\ (University of Pretoria)
}

\section{ABSTRACT}

Karl Barth's understanding of mission: The Church in relationship

As the Church is moving towards its $21^{\text {st }}$ century of existence, it is confronted by challenges it has never known before. This changing world demands self-reflection within the Church. It has to consider its place, identity and function, thereby giving rise to the exploration of its mission. In this article, the ecclesiology of Karl Barth is explored. By considering Barth's understanding of the Church's relationship with different parties such as God, other religions, those outside the Christian faith, the State and its own inner dynamics, the Church will be reminded of its missionary function in the world.

\section{INTRODUCTION}

Is the Church's missional function still valid in a world that is faced with ever increasing challenges? It seems that a world governed by modernist principles and challenged by post-modern philosophies, necessitates the need for the Church to think creatively about its mission. Barth's description of the Church's mission provides a good model that would facilitate such a process. This model focuses on the Church's relationships and defines mission accordingly. Before discussing Barth's definition of the Church as it exists in relationship with the different entities, attention needs to be given to Barth's description of the mission of the Church as found in Church Dogmatics.

\section{THE MISSION AND FUNCTION OF THE CHURCH}

Barth starts by defining the Mission and Function of the Church in Church Dogmatics Volume 1 (Barth 1956a:743-884) by describing

1 This article is based on research done for a $\mathrm{PhD}$ degree in the Department of Dogmatics and Christian Ethics of the Faculty of Theology at the University of Pretoria. The supervisor is Prof CJ Wethmar.

2 Dr Wessel Bentley is a part-time lecturer in the Department of Systematic Theology and Theological Ethics at the University of South Africa. 
the relationship between God's self-revelation and the Church's ability to engage with the revealed Word. This teaching on the Church's Mission and Function follows on from his Doctrine of Revelation (Barth 1956a:1-456) and the Doctrine of Holy Scripture (Barth 1956a:457-742). It is evident in the progression found in Church Dogmatics Volume 1, Part 2 that the Church's identity is founded on the premise that it exists as a response to the work that God has done. God reveals Godself, and so the revelation is received and appreciated by humanity in and through the power of the Spirit and, as a result, a community is established that continues the witness of those who have testified to God's self revelation as attested in Holy Scripture. The crucial question remains: If the Church is a testifying response to the revelation of God, how do we understand the mission of the Church in the light of its testimony? In order to address this question, a summary of Barth's position on the Church's function and mission is now given.

\subsection{The mission of the Church}

Barth (1956a:743) describes the Church's mission as "proclamation". In this section of Church Dogmatics, Barth (1956a:743-797) does not explore the nature of the Church's missionary proclamation in the different relational contexts, but describes the fundamental tensions that exist in the Church's role.

The first tension Barth points to, is the Church's recognition that there is a distinct difference between what he calls "The Word of God and the Word of Man” (1956a:743). By this is meant that when the Church engages in the practice of proclamation, it has to contend with the problem that its proclamation serves as a secondary process of communication that is subject to the initial act of God's selfdisclosure. This leads Barth (1956a:743) to ask the following questions: "Is the Church's preaching also God's Word, and to what extent? Is God's Word also the preaching of the Church, and, if so, is it valid?”

With the distinction made between the Word of God and the Word of Man [sic], the Church's proclamation can only be the Word of God in that it is a testimony about the Word, concerning the selfrevelation of God in God's Word. The testimony of the Church is therefore imperfect, because it is a proclamation based on the receipt and interpretation of revelation. Would it then not be better for God to rely upon God's own revelation in the "proclamation" of the 
Word? To Barth (1956a:745-755), God must be aware of this fundamental flaw in the Church's proclamation, but God must also resign Godself to the fact that this flawed testimony is the basis on which the Church communicates its understanding of, and relationship with God to the world. Revelation and proclamation are both therefore dependent on God's grace, for the Church (which consists of people) is confronted by the self-disclosure of a God who is beyond all creation's limitations. The Church is, at the same time, charged to testify in human language, symbolism and rituals, of a God who it cannot define empirically nor contain within the parameters of human communication.

The Church must therefore make certain admissions. The first is that the revelation of God is already complete outside its proclamation (Barth 1956a:749). God's self-disclosure is therefore not solely dependant on the Church's testimony, but is itself a proclamation before the Church can respond with its own testimony. This, to Barth (1956a:749), has already been achieved in Jesus Christ.

The second is the recognition that it is humanly impossible to speak about God using human language, reasoning and symbols (Barth 1956a:750). The Church's testimony cannot be engaged in the practise of defining God. Had it been tempted to limit the person of God to the expression of its own interpretation, the Church would be treating God as an object. By treating God as an object, the Church would be undermining the "otherness" of God and making God subject to its own biases.

The third is the recognition that "God...makes good what we do badly” (Barth 1956a:751). The Church's proclamation can be, and is used by God, while the Spirit of God works within the recipients of this proclaimed message and gives the gift of faith, thereby enabling the hearers of the testimony to respond to the Word of God.

To Barth (1956a:763), Christian proclamation is concerned with the teaching of doctrine. Doctrine is an instrument in the life of the Church, which directs its teaching and edifies the Church's ministerial task in the world. By subjecting its teaching to the direction of doctrine, the Church continues the Apostolic nature of its testimony, which is based on its understanding of God as revealed in Jesus Christ and testified to in Holy Scripture. The question 
resulting from this view then asks whether Barth's understanding of proclamation falls prey to Biblical interpretation, or at the other extreme, whether it becomes subject to positions held by the tradition involved in the proclamation of the Word. Barth (1956a:770) is very particular on the place and usage of doctrine. Doctrine is not shaped by the interests or the interpretation of what is perceived to be the revelation of God by a person or people. Pure doctrine is subject to certain conditions.

It requires the Church to measure its ability to speak about God (Barth 1956a:270) truthfully. This requires self-examination - the form of self-examination that forces the Church (in its formulation of doctrine and proclamation through preaching) to express itself in ways that indicate that it does not contain the Word of God in full. This forces the Church into a position where dogmatics is not only subject to the practices and duties of the Church, but that responsible God-talk (doctrine) is also possible outside the Church's life (Barth 1956a:770). The purity of doctrine comes into question when we consider that the Church's proclamation is done in a sinful human environment, using communicative mechanisms that are not designed to speak about a God who cannot be defined within the limitations of the created order (Barth 1956a:778-779).

"Dogmatics tests the Church's speech about God" (Barth 1956a:781). This implies that the Church's use of dogmatics becomes the basis of the Church's ethics (Barth 1956a:782, 793). It is the contextual proclamation of the Word of God in situations of human existence - subject to self-reflection and the continued evaluation of the validity of its proclamation - that represents the Word of God. The relationships investigated in this article describe these situations and therefore the Church's mission.

\subsection{The function of Dogmatics in the Church}

In the light of the Church's mission, Barth (1956a:797-884) goes on to describe the two-fold function of dogmatics in the Church. The first requires the Church to be a hearing ${ }^{3}$ Church (Barth 1956a:797). Barth (1956a:797) describes this function in the following way:

3 In Church Dogmatics (Barth 1956a:844) the words “listening” and "hearing" are used. The German text (Barth 1960b:890) contains the word "hören" and "hörende" for both these terms (interchangeably). It is my understanding that Barth conveyed the idea that the Church needs to be 
Dogmatics invites the teaching Church to listen again to the Word of God in the revelation to which Scripture testifies. It can do this only if for its own part it adopts the attitude of the hearing Church and therefore itself listens to the Word of God as the norm to which the hearing Church knows itself to be subject.

Dogmatics therefore informs the Church that God has spoken and that God continues to speak. The Church's existence and proclamation are not the initial announcement of God's selfrevelation. As much as the Church proclaims its testimony to the hearers of the Word, so it is also the recipient of God's selfdisclosure (Barth 1956a:800-801). What gives authority to the Church's testimony when it proclaims a Word that exists beyond itself? Barth (1956a:802) answers this question:

That Church proclamation is the Word of God means that God speaks as much for Himself in Church proclamation as He has spoken, speaks and will speak for Himself in Jesus Christ and in the prophets and apostles as witnesses to Jesus Christ. Therefore the formal task of dogmatics in regard to Church proclamation consists in confronting it with its own law in all its transcendence, in reminding it that it is the Word of God because Jesus Christ and He alone speaks in the prophetic and apostolic witness.

For this reason the Church falls victim to heresy when it fails in its hearing role and when it speaks about God from the basis of conclusions drawn, relying on its own strength and tradition and not on revelation (Barth 1956a:807). The Church has to live with the expectation that it hears the Word of God afresh (Barth 1956a:810) on a continuous basis. This prohibits tradition to take the place of God's self-revelation and will prevent the Christian Church's proclamation from being reduced to speculation.

At the disposal of the Church are two sources that test its listening: Scripture (Barth 1956a:816) and tradition (Barth 1956a:822). Both are historic testimonies of God speaking in the realm of creation and by subjecting its testimony to the scrutiny of these sources, it opens the way for the continuing apostolic nature of

available to receive God's self-revelation. It does so by hearing. When God reveals, the Church needs to listen and so become subject to the Word of God. 
the Church's witness. It also forms the basis for the unified nature of the Church proclamation, which from an outside perspective seems to be inconsistent as different traditions emphasise their respective doctrinal points of view. The hearing of the Church becomes impaired when sections of the Church allow divergent biblical interpretations and different historic traditions to take preference over the Church's witness.

True dogmatics and pure doctrine do not belong to any one strain of the Christian tradition (Barth 1956a:823), for this would imply that God says different things to different parts of the Body. To speak of a particular tradition's dogmatics must be done with the understanding that it belongs, and is subject to universal Church dogmatics (Barth 1956a:823).

The second function of dogmatics relates to the teaching Church. Barth (Barth 1956a:844) describes it in the following way:

Dogmatics summons the listening Church to address itself anew to the task of teaching the Word of God in the revelation attested in Scripture. It can do this only as it accepts itself the position of the teaching Church and is therefore claimed by the Word of God as the object to which the teaching Church as such has devoted itself.

As the relationship between the Word of God and the Church has its origin in revelation, so it also has a telos (Barth 1956a:845) that finds expression in the Church's teaching. The Church that hears the Word of God passively and does not actively respond to this selfdisclosure ceases to be the Church (Barth 1956a:845). The task of dogmatics is therefore to commit the Church to strive towards a teaching that is defined by doctrine using human language and symbolism as its means of communication (Barth 1956a:853). The measuring tools at the disposal of dogmatics are again Holy Scripture and tradition. The Church's testimony should not be presented in a way that renders the testimony of the self-revelation of God in Christ through Scripture and tradition meaningless (Barth 1956a:856). Dogmatic method also exists in the context of freedom and therefore requires the Church's obedience (Barth 1956a:861). Dogmatics in the Church is not static, but the Church itself adds to tradition and contributes to its own testimony in the future. Dogmatics as a system can only exist when it admits that the system itself does not contain the Word of God (Barth 1956a:866). It 
requires openness within the Church to receive truth (Barth 1956a:867) and to testify to that truth.

\section{The Church's relationships}

\subsection{A Church in relationship with God}

In order to discover the identity and mission of the Church, Barth (1981:442) makes the following statement: "The Church is not the Kingdom of God" - a sobering thought indeed.

Describing something via negativa is not always helpful, for it may leave a person in a place of ambiguity. It creates an environment for speculation, assumption and an opportunity to identify the entity at hand using subjective expectations. This is as far as we will take the via negativa argument, that the Church is not the Kingdom of God. This statement is important, for it forces the Church to step down from its place of power and "untouchability" and become subject to scrutiny. From this point, Barth is able to build an image of the Church which gives justice both to the Scriptural interpretation of the Ecclesia and the Church's existence in history.

The first building block is then the acknowledgement that the Church (and Church) does not exist because of its own initiative or planning, but that the Church exists because of God's work. The human element in history simultaneously cannot be denied. When we speak of humanity in this context, it refers solely to the Church's composition. The Church exists with a human membership, but did not come into existence because of it. The Church exists within a finely balanced framework: It is first the work of God, but also exists in history as a human activity (Barth 1956b:650). This creates a natural tension in the Church's identity. The Church celebrates the divine activity in its formation. The Church, according to Barth (1956b:644), is a direct result of God's revelation to creation through Jesus Christ, but is given life by the same Spirit that was part of the Incarnation.

Although it has a human "membership", the Church's primary responsibility is to acknowledge and exist within the fact that it is a product, an outcome of something done by God, not by itself.

This tension in the Church's identity beacons it to be extremely cautious in the way it approaches mission. In its existence as a divinely inspired and created community, the temptation exists to see 
itself as the sole voice of God. This implies that the Church occupies a place of power. Indeed, if we were to use a hierarchical structure to represent prominence and importance, the Church would be placed near the top, only to be superseded by God.

To Barth (1956b:658) this is a nonsensical assumption on the Church's part. It would make perfect sense if the Church were nothing but a human achievement on behalf of creation in its relationship with God. It would further make sense if God created the Church as an entity with little or no relational links with the world, but this is not where the Church finds itself. The Church cannot see itself in this place, for the Lord whom she acknowledges and worships advocated a life of service and obedience ${ }^{4}$ in the world. Being the Church in the world therefore does not call for a mission that is driven by its own importance or its own search for longevity. The Church in the world, representing the Church universal has the responsibility to point beyond itself and to point towards its Maker (Barth 1956b:658). The mission of the Church is not locked in an unapproachable point, which separates the Church and the world, but is defined in the Church's ability to exist in every level of reality and to point to its Lord from those places. This is nevertheless the gospel the Church refers to: concerning a Saviour that was, and is approachable and accessible to all.

Leading from this acknowledgment, the Church's identity and message is underscored by its, and the world's recognition that the Church (and Church) is not God. It is neither the full revelation of God, nor is it the sole mouthpiece of God in the world. An existential reality is that the Church is not divine itself, but is a point of contact between the Divine work and sinful people. Although the Church can claim that it comprises redeemed people, it has to do so in the full recognition that these same people are still sinners and in constant need of God's grace and redemption. From a missional position, the Church is in as much need of salvation as those to whom it witnesses.

If, as Barth (1956b:659) maintains, ecclesiology must take account of the ecclesia peccatrix then it would seem the "true Church" must be identified as both the Church whose sinfulness is overcome by the action of Jesus

$4 \quad$ See texts such as Mt 5:3-11, 18:1-5; Lk 14:25-33. 
Christ, and the Church which still sins (Barth 1958b:618). It would seem that within Barth's account, the eschatological dimension of the Church's existence might too easily be interpreted as an oscillation between a realized telos, rather than a telos which is never fully reached in this age, but may be glimpsed in a glass, darkly (Yocum 2004:118).

The Church cannot depend upon itself to be successfully involved in mission-activity, but it is its primary mission to look away from itself and to seek its Maker and Redeemer. It does so, noting that the Church's existence is dependant on the recognition of God's selfrevelation through Jesus Christ. The primary source that the Church can use to know about the Incarnation and self-revelation of God is in Holy Scripture (Barth 1958b:682-683). The way the Church engages with Scripture and uses Scripture is of utmost importance. Barth's use of Scripture is a helpful guideline ${ }^{5}$.

If the Church views Scripture as a message of love, an age-old record of people's testimonies of God's dealings with them, then the mission of the Church is to be an extension of the message of love revealed in Jesus Christ as anticipated by and reflected upon by the Biblical authors. This interpretation guards against a legalistic- and fundamentalist approach to Scripture, while allowing questioning of obvious contradictions and of that which seems, in our context, to be completely out of character to what we believe in the Christian life. In this open state, the Church is approachable to even the hardest critic without having to engage in apologetics.

The second tool at the disposal of the Church is Dogmatics (Barth 1956a:797), which must be the meeting point between what the Church believes and how it engages with the world. In essence it asks the question from various contexts: "Why do we believe what we believe and how does it impact on our perceived environment?"

The Church is not to be an uninformed Body, believing itself to be the sole recipient of God's self-revelation and existing

$5 \quad$ Engelbrecht (1986:4) describes Barth's view of Scripture by comparing the recipient of Scripture to a person in a concentration camp receiving a letter of love and encouragement. The letter may be torn, contain spelling mistakes, it may even have been intercepted and re-written, but the essence of the message is one declaring love. 
independently from the rest of the created order. The Church is the recipient of God's self-revelation as much as the world is the recipient thereof. Out of this act of grace, the Church comes into existence as an act of faith. In this faith, it pledges allegiance to God, while being painfully aware of its attachment to the world.

\section{A DIVERSE RESPONSE TO GOD AND THE WORLD}

\subsection{Introduction}

Perhaps the most confusing aspect of the Church's testimony is the manner in which the Church has responded with so many diverse perspectives, which have mainly found expression through the existence of different denominations within the Church. These different confessional movements within the Church have not always dealt with each other in grace, but here is where the Church has an extremely bloody history.

It is a reality in the existence of the Church that both the Church and the world will need to understand. More so the Church, because the way it has engaged with this specific issue is largely the measure of credibility that it carries. If the Church is not able to understand and work with its inner-diversity, then how can the world take its message of love, tolerance and reconciliation seriously?

So, the fact stands that in the Church's existence, we witness several different expressions of faith. This means that the Church is engaged in mission-activity within itself. To be in mission to itself means that the Church must consider it more important to see itself as a bearer of the testimony concerning its Lord, than to find the complete description of its identity in doctrine, confession or history (Barth 1956a:829). The testimony of the Church is nothing else but its witness of the risen Christ. Barth's ecclesiology emphasises this point and becomes the foundation of how the Church is to engage in any other doctrine.

From the publication of his Epistle to the Romans in 1919 to the very end of his life, Barth did not waver on this fundamental point: the reality to which theology refers is the eschatological reality of the risen Christ and the new life into which we are drawn by the Spirit (Dalferth 1989:21).

To be the Church in mission requires the Church's confession of faith in its allegiance to God and the profession of a community that 
finds its existence in the incarnation, life, death and resurrection of Jesus Christ. The way the Church understands this is obviously influenced by the Church's existence in time and space. History, culture and experience all have a valuable contribution to make in the Church's response to this revealed truth. This leads us back to the previous point concerning the Church's creation and composition. In testifying to its Lord, and in the search for some form of orthodoxy in its proclamation and expression, the Church has to be aware of its relationship with itself in the sense that different groups of Christians who are exposed to divergent influence may interpret, understand and express their faith to God in unique ways. Orthodoxy is therefore a goal and not a realistic claim by one group of Christians over another.

This does not mean that the Church's mission to itself must be coloured by a sense of denial. From the acknowledgement of the Church's own lack in finding the One truth within itself, it may be tempted to adopt a complacent attitude and become slack in engaging with different perspectives within itself. The Church needs to be aware of doctrinal differences that exist within itself and embrace it in its identity.

Barth (1956a:834) finds this practice of active engagement within the Church of utmost importance. To be the Church means to be in constant conversation with itself. Mission within the Church means to engage with itself concerning issues that seem insurmountable, especially when these issues are raised and carried by various denominational confessions.

One confession cannot see itself as being closer to the truth than another. This form of schism does not speak of the one Body of Christ, but is actively engaged in a form of amputation (Barth 1956b:675). If we were to adhere to the picture of the Church as Body, then it is obvious that diversity and different opinions is not something that the Church should be ashamed of, nor is it something that the Church should seek to destroy. The Church, with its various perspectives and unique expressions is still the Church. It represents a Body that transcends space and time, these dimensions compounding the diversity to that which already exists in the Church today. The Church is therefore a "coloured" community, one that holds onto one truth concerning its acknowledgement of Jesus Christ as its Lord. To perceive any difference in perception, interpretation and/or expression of this truth as being definitive in making one 
confession greater than another, is counterproductive and not helpful to the Church's mission in the world.

Does this mean that different movements within the Church should refrain from expressing their disapproval of practices in either the global Church or in other confessional movements? The obvious answer is "No!". What it should refrain from doing is allowing its objection to overshadow, or as in situations to be discussed shortly, to cause the Church to forget its missionresponsibility to the world around itself.

The greatest objection in Church history is found in the Reformation. This is a good example and one that Barth considered most in his discussion on work between the Catholic and Protestant traditions. To Barth (1961:64), both the Reformed and Lutheran traditions have ultimately failed their mission. These movements were extremely influential and successful in "protesting6", against the practices of the Catholic tradition. This "Protesting" by this movement was vital. There is no reason for anyone to suggest that the Reformation was ungodly or a waste of time. Many injustices were revealed, the Bible was made accessible to the laity and the Catholic Church was reminded, as in our first premise, that it was not God, nor the sole expression of God's self-revelation to the world. Its failings, to Barth (1961:64), lie in these traditions' overemphasis on protesting against the Catholic tradition, while not offering models of mission that are either more effective or necessarily more accessible. Although history will label the period of protest of the Reformed and Lutheran traditions against the Catholic tradition as the Reformation, very little reform took place in the Catholic strand of Christianity. Instead, we find schism, the breaking away of the Reformed and Lutheran traditions from Catholicism.

6 I acknowledge that the term "Protestant" is derived from "...the 'Protestatio' of the reforming members of the Diet of Speyer (1529) against the decisions of the Catholic majority" (Cross 1974:1135). "Pro testare" means "testifying for". The Reformers therefore "testified for" what they believed to be the true meaning of the Christian faith. The objection and protest against some of the Catholic doctrines and practices were subject to the proclamation of the Reforming members' own beliefs. By placing the emphasis on "protest" in the term "Protestant", I intend it to be interpreted as a form of indirect protest that emanates from the Protestant movement's "testifying for" its own stance. 
This schism has proven to be a long-term relational break between these traditions, adding to the history of the Christian faith another episode of division and bloodshed. Thanks to Vatican II and the signing of the Joint Agreement between Catholics, Lutherans and Methodists (World Methodist Council 2006) ${ }^{7}$ on an understanding regarding the doctrine of justification, do we find points of contact between these movements that are conducive to denominational engagement on further issues.

To be "protest-ant" means to reform and not to destroy, a concept close to Barth's (1961:64-65) heart. To be protest-ant, means to have the ability in faith to protest against practices in the Church that limit or hinder the proclamation of the Church's testimony. Where the Church freely and openly engages with itself, recognising that different voices in the Church have equal rights and opportunities for expression, there the Church has the best opportunity for reform to take place, while it simultaneously respects different perspectives. The Church's mission to itself is to facilitate the open and frank discussion between different Christian views, while ensuring the respect and dignified treatment of each tradition. Where reform takes place, it will be the result of the moving of God's Spirit in the Church and not because of human achievement.

The Church in South Africa is not immune to disagreements. A new protest has emerged in the Reformed tradition, calling itself "Die Nuwe Hervorming". I use this situation as an example of grappling within one tradition and do not mean to elevate the differences in these perspectives to the point where they become insurmountable. In a book published under the same title, authors ${ }^{8}$ protest against certain current Church practices that seem to be outdated and irrelevant, especially to those who are inclined to postmodern thinking.

Muller (2002:19-37), for instance, argues that the Church's doctrine and teaching is out of touch with modern questions. From this point, it is argued that the traditional interpretation in the Reformed tradition of Scripture does not seem to measure up to modern dilemmas. By this, the writer implies that the current

$7 \quad$ See Consulted literature.

$8 \quad$ Special reference is made to Muller (2002:19-37) and Craffert (2002:6787). 
Reformed perspective lends itself to a pious position where issues such as same-sex relationships and abortion are not openly received, nor dealt with in a manner that gives equal opportunity to "liberallyminded” Christians. Muller (2002:37) then calls for a revisiting of the Church's use of Scripture, to rethink its doctrine and become accessible to Christians who experience life in a much more complex manner than the old tradition would allow. Its use of Scripture and the standard of its doctrine is then labelled as "premodern” (Muller 2002:37). The danger that Muller perceives is that the Church could possibly be split between those using Scripture in the traditional fashion and a separate body of intellectuals and thinkers who interpret Scripture in a post-modern way. The interpretation of Scripture will therefore shape the doctrine of the Church. Craffert (2002:79) adds to this argument suggesting that the Church's current message cannot be understood by the post-modern world and that the Church needs to find ways in which to re-work the Christian message into a more relevant and understandable manner.

If we were to use Barth's understanding of how the Church is required to engage with itself, then we would need to pose questions. First, is equal opportunity given to all perspectives involved to voice their objections? Does either of these perspectives hold a moral high ground over the other? What is the motive of the protest - to reform or to destroy?

Taking the tone of the public discussion in local newspapers as a guideline, it does not seem as if these questions can be answered satisfactorily. The academic response has nevertheless been more accommodating, while at the same time being open and frank in its questioning. My main objection to "Die Nuwe Hervorming" is whether it is asking the Reformed tradition, and Christian faith in general to move into the field of apologetics. It seems as if the nature of the protest calls for a Church that needs to prove its relevance and voice in a world that experiences diverse issues and complex questions. Does the Church need to prove anything? By asking this question, I am not suggesting that the Church is beyond question. Where questions concerning life and faith arise, the Church must certainly be accessible, approachable and open to debate. A problem arises when the Church is defined according to popular culture and shaped, not by its identity in God's self-revelation in Jesus Christ, 
but by external issues. This negates the Church's need for doctrine and orthodoxy altogether.

Wethmar (2003:644) notes this movement's negative stance towards orthodoxy, especially the way in which it describes orthodoxy as being motivated by ideological constructs (2003:647). The conclusions that we can draw in such an argument is that orthodoxy becomes irrelevant when faced with a post-modern worldview. The Church nevertheless depends upon orthodoxy in order to be the prophetic voice, otherwise its testimony is compromised by its longing to fit into the constructs of its environment.

To Barth the Church is the context in which theology arises, the source of the content of theology and its purpose (1957a:17). Theology, the speaking about God, lends itself to different opinions. It cannot be otherwise. If theology were able to voice the ultimate truth without any sense of divergent views or controversies, then it would assume that the Church has gained the ability to understand fully the self-revelation of God. Not only would the Church then show its comprehension of the "person" of God, but it would also be able to make sense of God in the midst of its environment and experiences. For one group in the Church to negate fellowship for the sake of being right, goes against the nature of the Church's existence (Barth 1957b:529).

\subsection{One faith among many}

The Church's mission originates out of God's act of self-revelation to creation through which creation is able to respond in faith and so become a community. The nature of this community is one shaped by a total reliance on God's acts of revelation and salvation, while it is fully aware of its connection to the created realm. In this state of being, the Church also experiences different interpretations of its response to God and its interaction with its surroundings.

A further tension compounds the problem. The Church is not the only body claiming devotion to God, nor is it the only movement that claims to be a response to divine revelation. As much as differing opinions in the Church vie for a high-ground over each other, so the Church's primary reaction is naturally to claim that it is the only true and faithful response to God. 
From an objective perspective, the realms of religion may therefore seem to be in competition with each other, each attempting to convert and persuade members of other faiths to change and follow what it claims to be a "correct" interpretation of divine truth and the truest reflection of life as God intended it to be.

Barth was aware of the tension between the Church and other expressions of faith. To follow the progression of Barth's ecclesiology, it would become clear that the question that needs to be asked prior to asking, "Which religion is right?" is the question "What is religion?" Posing the former question before interrogating the nature of religion, leads us down a road carrying many assumptions concerning religion which render the investigation ineffective.

The first premise concerning religion in Barthian theology states that true religion is not about what we as human beings are able to achieve in terms of our relationship with God (Barth 1962:17). It can only exist because of God's self-revelation (Barth 1956a:302).

This definition automatically creates two different categories of religion. True religion is a result and response to God's selfrevelation. False religion is the consequence of humanity's initiated attempt to be in relationship with God. By using these constructs, different religions can be classified as either leaning towards the one approach or the other. "False religion" is evident in many of the primal-religions where the main focus is not a positive relationship with God (as a result of God's self-disclosure), but a human attempt to appease the gods by means of deeds or practices, aimed at ensuring the community's safety, prosperity and in a sense, tolerance on the gods' behalf.

Similarly an element of False religion is also present in the practice of what Barth describes as True Religion (1956a:284). This was obvious in the way Barth engaged with Liberal Theology of the $19^{\text {th }}$ and $20^{\text {th }}$ centuries. To Barth (1958a:48), the central focus of True religion is found in its understanding that it exists and is bound by God's covenant of love with creation, initially manifest in God's history with Israel, through which the intention of God's restorative relationship with creation is made clear. God's self-revelation therefore fulfils two roles. The first is to reveal God-self to creation 
while, simultaneously God's self-disclosure is the first redemptive act in creation.

As the Church responds to God's self-revelation by faith, specifically finding its identity in God's self-revelation in Jesus Christ, so the Christian religion moves from being a religion of revelation to being the revelation of religion (Barth 1956a:284).

In Jesus Christ, we find both the self-disclosure of God, as well as the revelation of human response to God. Jesus Christ is therefore the perfect expression of religion - displaying a natural relationship between God and creation. If Christianity, and more specifically the Church, exists purely for itself, trying to ensure its own identity and place in the midst of other religions, then Christianity can be denounced as a False Religion. The Church's mission is not to point to itself, not to ensure its own growth and existence. Its mission is to point to its Lord.

By bearing testimony to Jesus Christ, and by being Christfollowers, the Church therefore bears testimony to True Religion. It is not the perfect example of True Religion itself, but its mission is to point to the Christ-event. If this is the case, then the Church does not need to be in competition with any other religion. It ceases to be in competition, not out of an arrogant belief that it is right, but because the truth of religion is not found in the Church itself, but in the Church's Lord.

The Church therefore has a duty to exist in a world with diverse expressions of faith. It has a responsibility to exist in the context of different religions. Antagonism towards other religions and competition in quantitative terms have never won the Church many friends. The Church is an expression of faith as a result of God's self-revelation. The best it can do in terms of mission towards other religions is to point to God's self-revelation in Jesus Christ and bear testimony to the revelation of religion in the Christ-event. The Church is thus a celebration of faith, and not its champion. Its faith is assured of the victory and eternal righteousness revealed in Jesus Christ. It does not need to be in competition. It is not caught in arrogance, which thinks of itself as better than anything else, but is called to be in service to its Lord. Its motive is not to convert, but to witness the Lordship of Christ and so be an instrument of transformation and healing. It is concerned with reconciliation. Where conversion takes place, it must be said that it is not a result of 
the Church "winning another soul”, but can at best on the Church's behalf be an individual's response in faith to God's grace as testified to by the Church.

\subsection{A community with a testimony concerning election.}

Note that here Barth's understanding of Church is not described as "an elect community with a testimony", but the focus has shifted. It removes from the Church the responsibility to prove itself to be something more than it really is.

If the Church is a response to God's self-revelation, but is also created because of it, then the Church finds itself in a natural relationship with both other religions and those who do not adhere to any religion at all. The common factor is that they are all recipients of exactly the same self-disclosure by God in Jesus Christ. Barth explores the nature of this relationship even further. Not only is the Church a joint-recipient of God's self-revelation, but the Church with the rest of creation has become a community of the elect in Jesus Christ (Barth 1957b:35).

Election and revelation describe both the Church's relationship with God and with the rest of creation. It emphasises the nature of the Church being involved in True Religion, for it depends solely upon God's initiative for it to find existence and expression. Barth (1957b:19) maintains that God's election is not a decision made in response to the human condition of sin, but must be understood in terms of God's free decision to live in communion with creation, even before the Fall.

The election of creation then finds its full expression in the incarnation, life, death and resurrection of Jesus Christ, who is the expression of God's election (Barth 1957b:12), but is also the point in which God's election of creation becomes a reality. Christ is the full expression of God in creation and similarly of human obedience and faithfulness to God, thus confirming the Covenantal relationship between God and creation. With the Incarnation, the revelation of discipline and ethics required in the Kingdom of God are revealed (Barth 1957b:12-13).

As Christ reveals God - the full meaning of humanity in relationship with God and the norms of the Kingdom — so Christ paves the way for the realisation of a community that can respond to God in faith. This implies that the revelation of God's relationship is 
not only revealed to those who are prone to religious practices, but to all.

The Church is therefore also in direct relationship with those who do not confess faith in religious terms. As election takes place in the election of Christ, so the election of the community takes place (Barth 1957b:94). The Church is in this definition not the complete manifestation of God's elect (Barth 1957b:94), but is the expression of the elect who have responded to God's acts of grace in faith (Barth 1957b:196).

The election of the individual is therefore subsumed in the election of the community, which in turn is only possible through the election of Christ. The news to the Church in mission is therefore that all people are already elect in Jesus Christ, and thus find their redemption in the work of God and not in the work of the Church. Bosch (1980:166-167) describes the dynamics of this relationship well:

Our missionary activities, Barth argued, remained mere human efforts, unless it pleased God to incorporate them into the service of his revelation. For this reason our missionary motives would never be adequate. In our missionary reporting we should rather say too little than too much. After all, we could never establish the real need of the pagan; only God could know that. Similarly, we should not be too garrulous about the aim of mission; what we regarded as the main purpose could not remotely express what God's purpose was.

The possibility of the Church existing in the person of faith and the person "without" faith is equal. The Church's mission is not to differentiate between its mission to those of faith and those who do not adhere to a religious faith. It is not called to judge, but is called to witness.

To the devout Christian, this possibility hardly seems fair. How is it possible for God to love equally the person who does not respond to God's grace and the person who is in faithful service? The short answer is that if God depended on human works and achievements, we would then be faced with a Christianity of False Religion. The Church is called to proclamation, but it must be said that whether the Church engages in the verbal proclamation of its 
testimony or not, its mission is primarily to be present, available and accessible to all.

The Church's mission of presence creates the opportunity for individuals to respond freely to God's grace without feeling coerced, manipulated or threatened into the Kingdom. Bosch (1980:199) adds to this point:

Mission as an essential aspect of the Church's existence is also related to the fact that God's grace - in Barth's words - is never "brutal grace". God does not want to appropriate man to himself against man's will. He wants to offer man the opportunity to refuse God in liberty. And this opportunity which God offers man is called mission.

God elects all people in Jesus Christ. The election of the individual is bound in God's election of the community, but it becomes a living reality in the person's response of faith. The good news of God's grace is that it is not limited only to those who respond, but that God's acts of revelation and salvation are specifically for those who cannot respond in their own strength.

What would a Church look like that treats each person, whether that individual is part of the Christian faith, their denomination or not, as a being who is already elect in Jesus Christ and carries God's approval? Each person carries with them moral and ethical behaviour, whether outwardly or inwardly manifested, that may not carry God's approval.

The Church in this sense is in as much need of salvation as the person outside its fellowship. The matter of sin is an issue that requires a journey both with God and the community. The growing awareness of one's own sinfulness while in community with God and with others who profess a relationship with God is precisely the journey of faith, hope and love. It is the path of healing, the process of sanctification.

The Church's mission is then portrayed in the way it interacts with those who do not form part of its community. The inclusive and welcoming practices of the Church should testify to its recognition of God's acts of revelation and salvation to each person in Jesus Christ. Church practices, especially the sacraments therefore cannot 
be used as instruments of punishment ${ }^{9}$. Church practices, particularly the sacraments, must be seen in the light of a celebration of God's acts of love that cannot be confined by the Institutional Church. The sacraments are not a right of passage to the grace of God, nor are they proof of God's acts of love in the community or the individual.

When it comes to the point about Baptism, Barth's understanding of this Sacrament gives sufficient theological reason to combat the idea of a differentiation between personal salvation as the first divine act in the life of the individual and then Baptism of the Spirit (which accompanies adult Baptism in many Pentecostal Confessions) as a second divine act or "Second Blessing" (Floor 1986:11). Such a proposal is heresy, bordering on blasphemy.

The Church's fellowship, accessibility and open witness to its Lord in worship and service are all part of the Church's mission to those outside its expression of faith.

\subsection{An instrument alongside the State}

The Church's mission, stemming from its creation in God's selfrevelation and from its relationship with those who exist within and alongside it lead the Church to another form of mission. The Church, dealing with people, also has to interact with institutions that govern, shape and guide humankind. This places the Church in a relationship with the State. The world, which the Church serves and to whom the Church testifies concerning God's revelation in Jesus Christ, is governed by politics.

The Kingdom of God is not an immediate global reality, but in the Church's existence, is an eschatological goal in creation. As much as the Church has been engaged in the world, and with politics, history has shown various reactions by the Church to the State. These vary from full participation with the State as displayed in the Roman Church's influence in the pre-Reformation era, the

9 This is the case in many denominations where a Church member who is under discipline is refused access, specifically to Holy Communion. The Roman Catholic Catechism employs this in the discussion on excommunication by stating that such discipline "....impedes the reception of the sacraments and the exercise of certain ecclesiastical acts, and for which absolution consequently cannot be granted, according to canon law, except by the Pope, the bishop of the place or priests authorized by them" (Catechism 1992:366). 
Reichskirche in Germany during the early $20^{\text {th }}$ century and the Reformed tradition's (in South Africa) endorsement of the Apartheid regime in South Africa during the mid to late $20^{\text {th }}$ century. On the other extreme, there have been movements in the Church protesting against the named Church's stances and segments of different denominations that have refused to participate in discussion and simply removed themselves ${ }^{10}$ from this fellowship between State and Church, whatever the relationship may have been.

Barth is direct concerning the place of Christian engagement with the political realm. To Barth, Christians are not called to be passive observers of their situation (Barth 1956a:711), but carry a responsibility both as people of faith and citizens of their respective countries to engage with the powers and facilitate discussion, especially concerning matters that are against the morals and principles of the Christian faith.

Shall the Church then view the State as an entity that exists as the human effort to bring about justice, peace and the ideals of the Church? It may be tempted to do so and then label the State as a form of False Religion, but this is not the case. Barth (1960a:144) describes a very delicate relationship between the Church and the State.

On the one side, the Church has the responsibility to observe and critique the State's actions. Nevertheless, it has to do so using a very specific point of reference. Its own identity in engaging as both observer and critic of the State is not undertaken with the understanding that the Church possesses a higher morality, divinity or divine perspective. Neither can it engage in these acts, pretending to be an opposition-party to whatever political party is in power.

The Church's main perspective arises from the call to be in partnership with the State (Barth 1960a:144). This may be an extremely sobering concept for the Church. The notion in the Church that it is the sole builder of the Kingdom of God is therefore denied. Once again, we must be reminded that the Kingdom of God is not one built by human initiative, but is purely God's act of grace, facilitating creation's response in faith. The Church is not the Kingdom of God.

10 The Kairos document describes this position as "Church Theology" (Kairos 1985:11-17). 
This point also reinforces the concept that God's act of revelation, salvation and thus election exists beyond the measurable points of the Christian Church. Where the Church is called to testify a message of hope, the State receives a similar call, but this time a call that directs this instrument to oversee and promote the wellbeing of its citizens (Barth 1981:445). Where the Church points towards Christ, specifically encouraging spirituality, there is a certain moral-standard that is proposed in the Person of Jesus Christ (Barth 1981:442). The State, on the other hand has a responsibility to look after its citizens and to promote a sense of community (Barth 1981:445).

The Church can therefore dedicate its mission to the State largely as one of intercessory prayer (Barth 1960a:135) but its mission to the State does not end here. As a witness of God's selfrevelation, and having responded to God's call to be Christfollowers, the Church bears the responsibility to participate with the State in promoting justice, peace and righteousness.

This model does not juxtapose the Church in opposition to the State, but takes cognisance of the fact that, serving in the State are people who have very strong religious convictions. The Church is therefore not separated from the State, but has a part in it and vice versa.

The Church should nevertheless guard against the temptation to dictate to or aim to replace the State. Another caution would be the antithesis: to prevent the State from dictating to or aiming to take the place of the Church.

\section{CONCLUSION}

The notion of mission in Barth's ecclesiology has shown surprising results. Mission is a result of the Church's existence as the Church discovers itself and asks questions about its identity. The Church's primary relationship with God requires the Church to be in mission. The relational ties between the Church and God as well as the Church and the world define the manner in which the Church exercises its missionary objectives. Throughout the discussion, it has been evident that the Church's first missional priority is to be the bearer of the testimony concerning God's self-revelation and salvific acts. The crux of this testimony centres around the Church's relationship with Jesus Christ as its Lord. 
From here, the Church develops further relationships and its testimony becomes defined and focussed according to these relationships. It is important to note that the essence of the Church's message does not change as the Church engages with these different parties. The manner in which the Church professes Jesus as its Lord becomes more deliberate and relevant as it learns to be a witnessing body that is simultaneously in relationship with God and the world. As the dynamics in the relationship between the Church and these different entities change, so does its missional function and role. Although the Church's proclamation is in essence the same, always pointing to Jesus Christ, it has to continually assess its relationship within itself, to the world, other religions, the "religionless" and the State in order to communicate this message in a meaningful manner.

\section{Consulted literature}

Barth, K 1956a. Church Dogmatics I/2: The doctrine of the Word of God. Edited by GW Bromiley and T F Torrance. Translated by H Knight and GT Thomson. Edinburgh: T\&T Clark.

-, 1956b. Church Dogmatics IV/1: The doctrine of reconciliation. Edited by G.W Bromiley and T F Torrance. Translated by GW Bromiley. Edinburgh: T \& T Clark.

-, 1957a. Church Dogmatics I/1: The doctrine of the Word of God. Edited by GW Bromiley and TF Torrance. Translated by GT Thomson. Edinburg: T \& T Clark.

-, 1957b. Church Dogmatics II/2: The doctrine of God. Edited by GW Bromiley and TF Torrance. Translated by GW Bromiley and JC Campbell, H Knight et al Edinburgh: T \& T Clark.

-, 1958a. Church Dogmatics III/1: The doctrine of creation. Edited by GW Bromiley and TF Torrance. Translated by O Bussey, JW Edwards and $\mathrm{H}$ Knight. Edinburgh: T \& T Clark.

-, 1958b. Church Dogmatics IV/2: The doctrine of reconciliation. Edited by G W Bromiley and T F Torrance. Translated by G W Bromiley. Edinburgh: T \& T Clark.

-, 1960a. Community, State and Church: Three essays. Translated by A M Hall and G R Howe. Gloucester: Peter Smith.

-, 1960b. Die Kirchliche Dogmatik I/2: Die Lehre vom Wort Gottes. Zürich: Evangelischer Verlag.

-, 1961. Church Dogmatics III/3: The doctrine of creation. Edited by GW Bromiley and TF Torrance. Translated by GW Bromiley and RJ Ehrlich. Edinburgh: T \& T Clark.

-, 1962. The Christian life. Translated by J S McNab. Lexington: Student Christian Movement Press. 
-, 1981. Ethics II. Ethics. Edited by D Braun and translated by G W Bromiley. Edinburgh: T \& T Clark, 261-521.

Bosch, D J 1980. Witness to the world: The Christian Mission in Theological perspective. London: Marshall, Morgan \& Scott.

Craffert, P F 2002. Die Nuwe Hervorming - Wat, waaroor en waarheen? in Muller P (ed), Die Nuwe Hervorming. Pretoria: Protea Boekhuis, 67-87.

Cross, F L (ed.) 1974. The Oxford Dictionary of the Christian Church. Oxford: Oxford University Press, 1135.

Dalferth, I U 1989. Karl Barth's eschatological realism in Sykes, SW (ed), Karl Barth: Centenary Essays, Oxford: Clarendon Press, 14-45.

Engelbrecht, B J 1986. Twee vroeë reaksies van Gereformeerde kant op Karl Barth, In die Skriflig 20, 2-9.

Floor, L 1986. Barth en die Kinderdoop, In die Skriflig 20(78), 10-19.

Muller, P (ed) 2002. Die Nuwe Hervorming. Pretoria: Protea Boekhuis.

Muller, P 2002. Die Postmoderne gelowige in Muller, P (ed), Die Nuwe Hervorming, Pretoria: Protea Boekhuis, 19-37.

Sykes, S W (ed) 1989. Karl Barth: Centenary Essays. Cambridge: Cambridge University Press.

The Kairos Theologians. 1985. Challenge to the Church: A theological comment on the political crisis in South Africa (The Kairos Document). Braamfontein: The Kairos Theologians.

The Roman Catholic Church. 1992. The Catechism of the Catholic Church. Nairobi: Pauline Press.

Wethmar, C J 2003. Teologiekroniek: Die Nuwe Hervorming en die Ortodoksie in Verbum et Ecclesia 24(2). Pretoria: Medpharm Publications, 644-649.

World Methodist Council. 2006. "The World Methodist Council and the Joint Declaration on the Doctrine of Justification". http://www. worldmethodistcouncil.org/files/world_methodist_council_and_the_jddj.pd $\mathrm{f}$ (Accessed on 28 February 2007).

Yocum, J 2004. Ecclesial mediation in Karl Barth. Burlington: Ashgate Publishing Company. 